\title{
GC-MS analysis and antibacterial activity of the Sea cucumber (Muelleria lecanora) extract
}

\author{
Muhammad Yusuf, ${ }^{1}$ Nur Fitriani Usdyana Attahmid ${ }^{2}$ \\ ${ }^{1}$ Department of Chemical Engineering; ${ }^{2}$ Department of Agroindustry, Politeknik Pertanian Negeri Pangkep, Pangkep, \\ Indonesia
}

\begin{abstract}
Sea cucumbers are marine invertebrates commonly found in benthic areas and deep seas. On a global scale, they have a high commercial value with an increased level of production and trade. This study aims to analyze the bioactive compound in Sea cucumber (Muelleria lecanora) using the Ultrasound-Assisted Extraction Method (UAE) and Gas ChromatographyMassSpectrometry (GC-MS). Furthermore, it identifies the antibacterial activityin microorganisms Salmonella, Escherichia coli, and Staphylococcus aureus. The bioactive compounds were extracted using methanol, acetone, and n-hexane solvent and were separated by ultrasound-assisted extraction. In the initial stage, phytochemicals were screened using Gas Chromatography-MassSpectrometry (GC-MS). Disc diffusion method was then used to determine theantibacterial activity against Salmonella, Staphylococcus aureus, and Escherichia coli. The results showed that methanol extract is more suitable
\end{abstract}

Correspondence: Muhammad Yusuf, Department of Chemical Engineering, Politeknik Negeri Ujung Pandang, 90245 Makassar, Indonesia.

E-mail: yusufitri@poliupg.ac.id

Keywords: antibacterial; Muelleria lecanora; phytochemicals; sea cucumber;ultrasound-assisted extraction.

Acknowledgements: The authors are grateful to Politeknik Negeri Ujung Pandang for providing research facilities and equipment.

Conflict of interest: The authors have no conflict of interest to declare.

Funding: The author(s) received no financial support for the research, authorship, and/or publication of this article.

Received for publication: 19 March 2021.

Revision received: 23 June 2021.

Accepted for publication: 21 August 2021.

${ }^{\circ}$ Copyright: the Author(s), 2021

Licensee PAGEPress, Italy

Journal of Biological Research 2021; 94:9765

doi:10.4081/jbr.2021.9765

This article is distributed under the terms of the Creative Commons Attribution Noncommercial License (by-nc 4.0) which permits any noncommercial use, distribution, and reproduction in any medium, provided the original author(s) and source are credited. for extracting bioactive compounds of Muelleria lecanora than acetone and n-hexane. Meanwhile, acetone solvents are more suitable for the production of flavonoid and steroid compounds than Mulleria lecanora samples. Heneicosane compounds that function as a new antiproliferative for inhibition of tumor and cancerous cells are produced from n-hexane. The antibacterial activity of acetone, methanol and n-hexane extract determined by diffusion assay was effective against Staphylococcus aureus and Salmonella but ineffective againstEscherichia coli. GC-MS results showed that the major constituents obtained were steroid and flavanoid. From this study, Sea cucumber extract can be considered a healthy nutrientin food and pharmaceutical products.

\section{Introduction}

Sea cucumbers are invertebrate found in various marine habitats and are specially cultivated by countries in East Asia such as China and Japan. ${ }^{1}$ The majority of countries that consume sea cucumbers are located in Indo-Pacific Asia, including Hongkong, Malaysia, Indonesia, Japan, Singapore, South Korea, Philippines, and China. ${ }^{2}$ Sea cucumbers have complete nutritional content with low-fat, high protein, and rich in essential amino acids, such as lysine, arginine, and tryptophan. ${ }^{3}$ They have a body wall composed of non-soluble collagen and is utilized as a dietary supplement. ${ }^{3}$ Furthermore, they reduce arthritis pain because of a rich source of chondroitin sulfate polysaccharides. ${ }^{4}$ Sea cucumbers(Holothuroidea)are thorn-skinned marine animals with potential as a source of pharmacology and can be processed as food. Furthermore, they are known as gamat and beche-de-mer, and are used in medical systems of the middle eastern society and Asian people. ${ }^{5}$ They are also recognized as a traditional remedy for treating asthma, rheumatism, hypertension, impotence, constipation, and burns. ${ }^{6}$ Other functions include anti-coagulant, anticancer, anti-inflammatory, antithrombotic, antimicrobial, antioxidant, antiangiogenic antihypertensive, anti-tumor, and healing wound. These bioactive compounds of saponin, phenolics lectins, sterols, peptides, glycosaminoglycan, chondroitin sulfate, cerebrosides, and sulfate polysaccharides can be used as a potential antibacterial. These substances suppress the growth and development of bacteria in the sea. The need for new antimicrobial materials increases because the growth and development of bacteria are currently resistant to antibiotics in addition to the growing conventional antibiotics. ${ }^{7}$

A study onthe sea cucumbers Holothuria scabra and Holothuria leucospilota, from the northern coast of the Persian Gulf, showed the antibacterial and antifungal effects on Aspergillus 
niger, Candida albicans, Escherichia coli, Pseudomonas aeruginosa, and Staphylococcus aureus. ${ }^{8,9}$ In another in vitro study, the antibacterial effects of the sea cucumber Apostichopus japonicus against Micrococcus lysodeikticus, Streptococcus dysgalactiae, Nocardiopsis, Pseudoalteromonasnigrifaciens, and Shewanella baltica ${ }^{10}$ Antibacterial activities of extracts from different organs (gonad, body wall, respiratory tree, and digestive tract) and antifouling of the sea cucumber Holothuria leucospilota against bacteria Staphylococcus aureus was also conducted. ${ }^{11}$ In the same study, Stichopus hermanni, Thelenota ananas, Thelenota anax, Holothuria fuccogilva, and Actinopyga mauritiana have potential as antibacterial. ${ }^{12}$ These functional materials lead to potential developments in the various food and biomedicine industries. The study presented a general view of the major medicinal and health benefits of functional sea cucumbers from the Asian region.

A few conventional methods (e.g., Maceration, EnzymeAssisted Extraction (EAE), Ultrasonic Assisted Extraction (UAE), Microwave Assisted Extraction (MAE), Heat Reflux, and Mechanical Rabbling) were utilized for the extraction of target compounds from crude materials. ${ }^{13}$ Ultrasound can hydrate and facilitate swelling of vegetal tissue. It increases mass transfer and allows high diffusion rates across the cell. In contrast, cavitation produced by ultrasonic waves disrupts the cell, then releases contents. ${ }^{14}$ Some related studies, such as the use of ultrasound methods, high hydrostatic pressure, and high electric field pulse were widely applied to the rehydration process to improve the mass-liquid displacement. Furthermore, the use of energy produced by high-frequency sound waves above $16 \mathrm{kHz}$ was widely regarded as one of the most effective technologies. A previous study on sea cucumber extracts' antibacterial activity was reported against various pathogenic bacteria such as Listeria,Staphylococcus aureus, Escherichia coli, and Salmonella. ${ }^{15} \mathrm{~A}$ study for antimicrobial activities and antioxidants was significantly conducted, and the potential was examined through ultrasonic-assisted extraction with time variations $(30,60,80$, and $120 \mathrm{~min})$. The efficiency of various solvents (acetone, n-hexane, and methanol) for the phytochemical extraction of Sea Cucumber Muellaria and the identification of bioactive compounds were analyzed using GC-MS (Gas Chromatography-Mass Spectrometry).Furthermore, antibacterial efficacy against pathogenic bacteria Escherichia coli, Salmonella, and Staphylococcus aureus was conducted using disc diffusion methods.

\section{Materials and Methods}

\section{Materials}

The sea cucumber phylum Echinodermata, family Holothuriidae and genus Muelleria lecanora (Figure 1) werecollected from the coast of Barrang Lompo Island in Makassar, South Sulawesi, Indonesia. During the trip, they were stored in a cooling box that contains an ice pack. The storage, preparation, and analysis of samples were conducted in the Chemical and Instrumental Analysis Laboratory, Chemical Engineering Department, Politeknik Negeri Ujung Pandang, Indonesia.

The solvents used for sample extraction and reagents of analytical grade, aquadestilata, methanol, n-hexane, acetone, McFarland Standard (barium chloride and sulfuric acid), $\mathrm{pH}$ paper, antibiotic disc blank (Whatman No.1 and 5), dimethyl sulfoxide, and sodium chloride were supplied by Merck Millipore (Burlington, Massachusetts, United States). Tetracycline hydrochloride was provided by Sigma Aldrich (St. Louis, Missouri, United States).

Bacterial strains Salmonella (ATCC 13076), Escherichia coli (ATCC 25922), and Staphylococcus aureus (ATCC 25923) were obtained from Microbiology Laboratory. Department of Biology, State University of Makassar, South Sulawesi, Indonesia. Furthermore, the isolated bacteria grew at a temperature of $32^{\circ} \mathrm{C}$ in nutrient broth (DIFCO Laboratories, Detroit, USA) following standard procedures. ${ }^{16}$ Media growth nutrient agar and plate count agar were purchased from Oxoid, Basingstoke, United Kingdom.

The tools used include water bath (Memmert WNB 7 Basic control) Hettich Zentrifugen EBA-20, rotary evaporator Buchi, Hitachi centrifuge brands, Ultrasonic Assisted Extraction instrument (Elmasonic P30), and Shimadzu GC-MS 2010 brand Gas Chromatography-Mass Spectrometry plus.

\section{Process for the preparation of extracts}

The sea cucumbers were wiped clean and dried in an oven at $70^{\circ} \mathrm{C}$, then cropped and minced.Furthermore, $100 \mathrm{~g}$ was weighed, homogenized, and extracted using an ultrasonic-assisted extraction method with a ratio volume of 1:2(V/V) methanol, acetone, or $n$ hexane for $30,60,90$, and $120 \mathrm{~min}$. This was conducted in the rotary evaporator at $39^{\circ} \mathrm{C}$, followed by a shaker for $24 \mathrm{~h}$ at a temperature of $10^{\circ} \mathrm{C}$. The supernatant was centrifuged for $10 \mathrm{~min}$, and
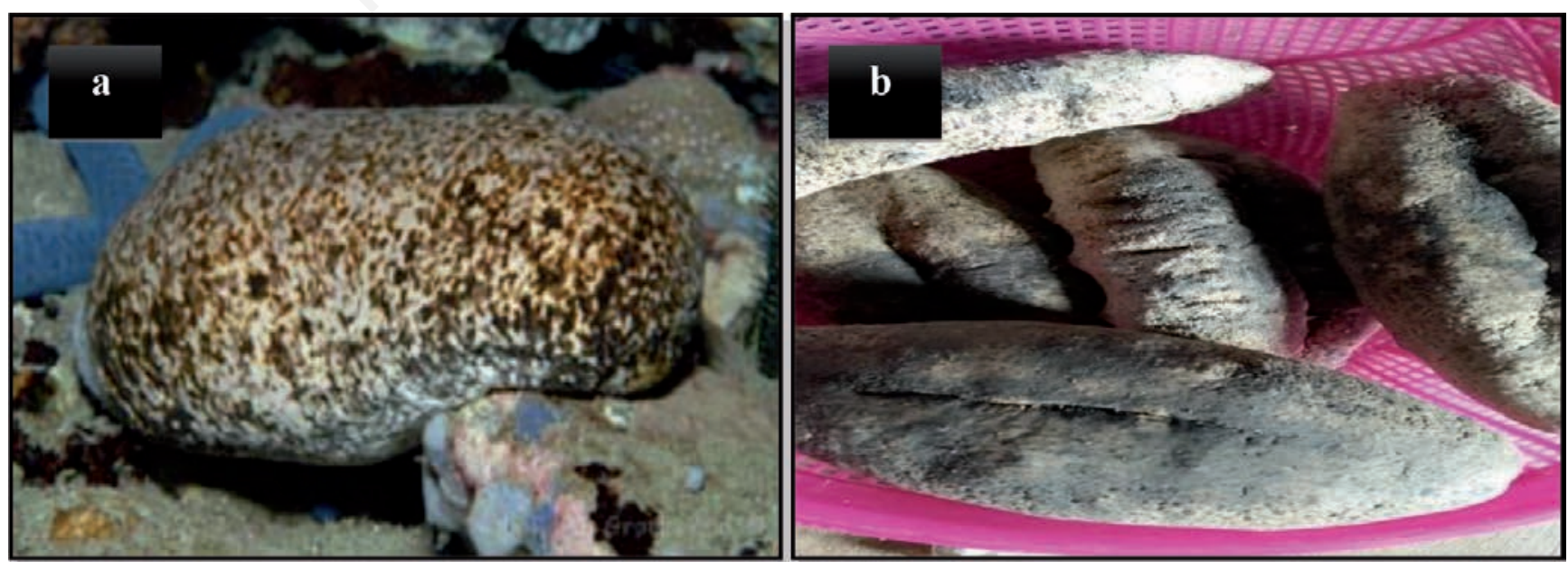

Figure 1. Sea cucumber Muellaria lecanora: a) fresh, and b) dried. 
its bioactive compounds were analyzed using GC-MS. Furthermore, the antibacterial activity was conducted through the disc diffusion method.

\section{Gas Chromatography-Mass Spectrometry (GC-MS) Analysis}

Flame Ionization Detector (FID) in EI mode at $70 \mathrm{eV}$ and capillary column DB-5 ( $30 \mu \mathrm{m}, 0.25 \mathrm{~mm}, 0.25 \mu \mathrm{m}$ film) were used to test the sea cucumber using GC-MS. $1 \mathrm{~mL}$ of the extract was added with $3 \mathrm{~mL}$ of methanol $96 \%$ in the reaction tube and vortex. The temperature of injectors and the detector was $250^{\circ} \mathrm{C}$ and $220^{\circ} \mathrm{C}$, one sample dissolved with $1 \mu \mathrm{L}$ methanol was injected and analyzed for $2 \mathrm{~min}$ at $60^{\circ} \mathrm{C}$ and increased to $300^{\circ} \mathrm{C} / \mathrm{min}$ at $3^{\circ} \mathrm{C}$ with Helium (He) gas carrier at $1 \mathrm{~mL} / \mathrm{min}$. This generated two $\mathrm{GC}$ data in the form of the chromatogram, which displays the compound's peaks in the methanol, acetone, or n-hexane extract. The current MS (Mass Spectroscopy) data showed the molecular weight at each peak. Any peaks appearing on the GC chromatogram indicated a single molecule and have a fragmentation pattern displayed in the MS spectra. The fragmentation pattern was used to identified organic compounds contained in the sea cucumber sample.

\section{Antimicrobial assay}

Disc antibiotic blank (Whatman No. 1) was cut and sterilized with other equipment using autoclaved at $121^{\circ} \mathrm{C}$ for $15 \mathrm{~min}$. Growth media microorganisms are $5 \mathrm{~g}$ nutrient agar (NA)with dissolved $250 \mathrm{~mL}$ of aquades in the Erlenmeyer $500 \mathrm{~mL}$ heated to homogeneous. Furthermore, $0.9 \mathrm{~g} \mathrm{NaCl}$ was dissolved in a $100 \mathrm{~mL}$ volumetric flask, and inserted into the reaction tube of $9 \mathrm{~mL} . \mathrm{Mc}$ Farland solvent was obtainedby mixing a solution of barium chloride $\left(\mathrm{BaCl}_{2}\right) 1.175 \%$ and sulphuric acid $\left(\mathrm{H}_{2} \mathrm{SO}_{4}\right) 1 \%$. Mc Farland $0.5 \%$ was used as standard turbidity (absorbance $600 \mathrm{~nm}$ ). Media nutrient agar and sodium chloride solvent sterilization was conducted using autoclave at temperature $121^{\circ} \mathrm{C}$ for $15 \mathrm{~min}$.

Sterile nutrient agar $20 \mathrm{~mL}$ was poured in Petri dishes and was inoculated at $37^{\circ} \mathrm{C}$ evenly with $0.1 \mathrm{~mL}$ of a $24 \mathrm{~h}$ broth culture of test bacteria. ${ }^{17} \mathrm{Sea}$ cucumber extract $0.25 \mathrm{~g}$ was dissolved in $1 \mathrm{~mL}$ aqueous dimethylsulfoxide ( DMSO) with tween 80 $(0.5 \% \mathrm{v} / \mathrm{v}$ for easy diffusion) and filtered through a $0.45 \mu \mathrm{m}$ membrane filter. In addition, each sterile disk (Whatman $6 \mathrm{~mm}$, number 5) was dipped in $20 \mu \mathrm{L}$ of extracts and carefully put on the agar plate using flame sterilized forceps to ensure the disks were at least $2 \mathrm{~cm}$ apart. The plates were inverted after $30 \mathrm{~min}-$ utes and incubated at $37^{\circ} \mathrm{C}$ for $48 \mathrm{~h}$. This was followed by measuring the inhibitory zone for each sample and the type of bacteria in $\mathrm{mm}$. The test was performed in duplicate, and the mean area inhibition diameter was reported. Furthermore, negative controls used a $10 \%$ DMSO solvent, and one paper disc was given a tetracycline $\mathrm{HCl}$ as a positive control. Classification of the antibacterial activity was conducted and $10 \mathrm{~mm}$ diameter was considered active, while less was inactive. ${ }^{18}$

\section{Results and Discussion}

\section{Yield analysis extract of acetone, $n$-hexane, and methanol}

Figure 2 showed that the extraction time affected sea cucumbers production obtained by various solvents (acetone, n-hexane, methanol) and time extraction $(30,60,90$, and $120 \mathrm{~min})$. The study results showedthat the highest yield ofMuelleria lecanora extraction uses solvents (methanol, acetone, and n-hexane). The highest yield on the extraction was with methanol solvent of $11.2 \%$ and the lowest was $n$-hexane of $1.86 \%$. Yield analysis on methanol, acetone, and n-hexane extract obtained a range of 6.04-11.2\%, 4.46$6.83 \%$, and $1.1-1.8 \%$. The ultrasonic-assisted method showed a direct proportionality with extraction time and the resulting crude extract. A study by Yusuf et al. ${ }^{19}$ stated that the length of time for the extraction process is very influential in the resulting extract. Therefore, increasing the time from 30 to 120 min using differents solvents significantly increased the yield of sea cucumbers. The yield obtained was directly correlated with an increase in extraction time (Figure 2).

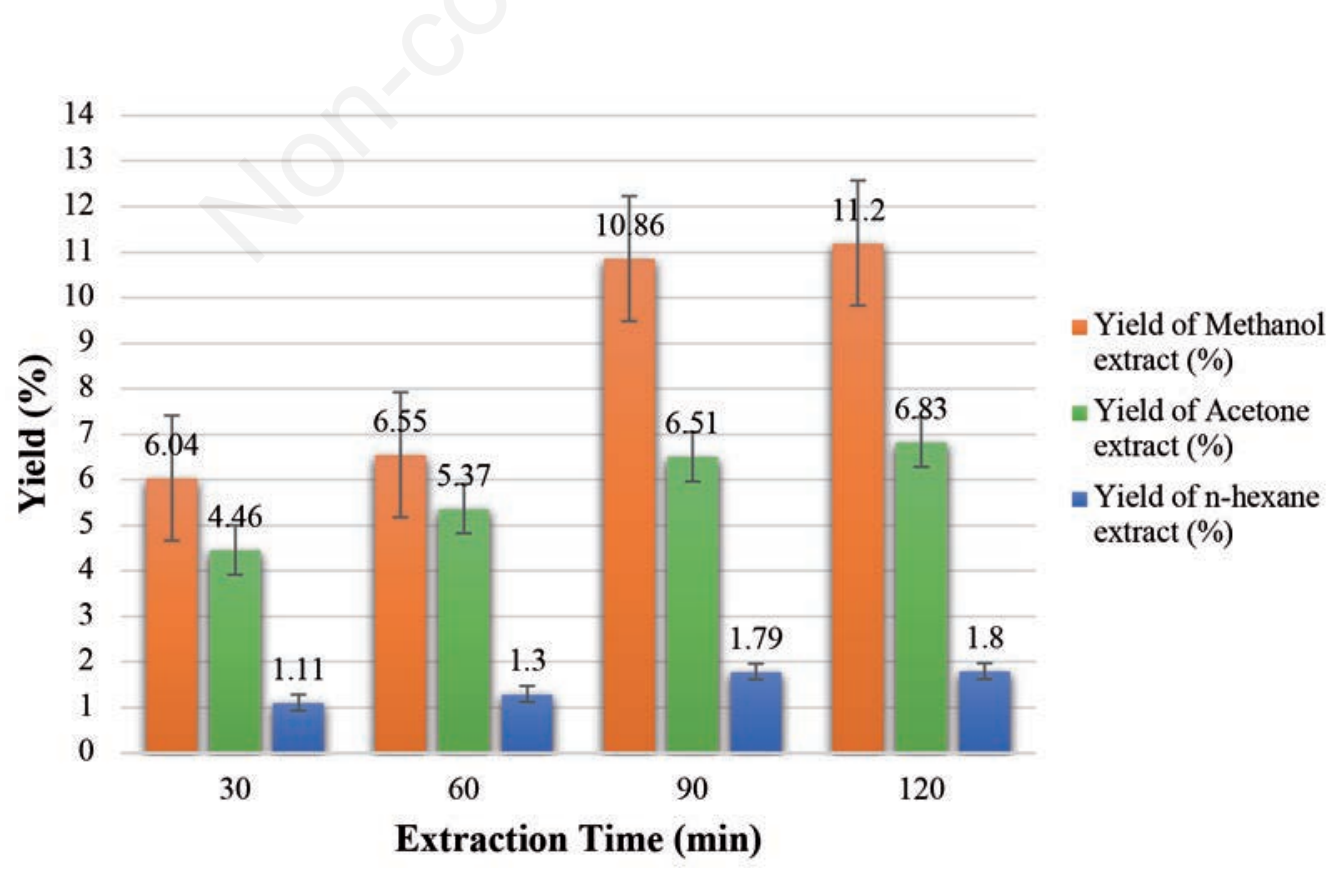

Figure 2. Effect of different solvents and time to extract sea cucumber yield. 


\section{GC-MS profile bioactive compound of Muelleria lecanora}

Table 1 showed the availability of a bioactive compound in the methanol acetone and n-hexane extract of Muelleria lecanora characterized by GC-MS. The acetone extract of sea cucumbersMuelleria lecanorahad a running time of $39 \mathrm{~min}$ forGC and MS spectrum (Figure 3). Chromatogram evaluation of the acetones extractsconfirmed sixty major peaks and determined the components. Major component of this extract are as follows 9-Octadecenoic acid (Z) -, methyl ester (7.36\%), Azulene,1,2,3,5, 6,7,8,8a-octahydro-1,4dimethyl-7-(1-methylethenyl)-,[1S-(1.alpha.,7.al (7.53\%), Stigmasta -5,22-dien-3-ol, acetate, (3.beta.) (8.86\%), Hexadecanoic Acid, Methyl Ester (11.2\%), and Cholest-5-EN-3-YL Acetate (13.61\%), which is an antioxidant and antibacterial component. Pharmacologically, azulene compounds exhibit antipyretic properties, anti-inflammatory drugs, and cardiac tonic..$^{20,21}$
Figure 3 showed that the spectrum for GC and MS run time for the Muelleria lecanora methanol extract was $39 \mathrm{~min}$. The result analysis includes their component quantity, molecular formula, and composition within the Muelleria lecanora methanol extracts. Table 1 showed the percentage composition and list of known compounds. Many of the antioxidants and antimicrobials were present in trace levels, a complex mixture of numerous compounds;9Hexadecenoic acid, methyl ester, (Z) (1.54\%), Omega 3/5,8,11,14Eicosatetraenoic Acid, Methyl Ester, (ALL-Z) EPA (2,59\%), Ergosta-14,22-Dien-3-OL, Acetate, (3.Beta.,5.Alpha.,22E)- (4.7\%), Cholest-5-EN-3-YL Acetate (7.64\%), 2[(Hexadecyloxy)Methyl]Oxirane (9.34\%), Octadecanoic acid, methyl ester (13.34\%), 9-Octadecenoic acid (Z), methyl ester (stearic acid methyl ester, 14.42\%), Hexadecanoic Acid, Methyl Ester (17.36\%), performs a crucial role. Furthermore, steroids and flavonoids were the significant components in the sea cucumber, which was rich in glycosides and triterpene with proven antifungal

Table 1. GC-MS report for methanol, acetone, and $\mathbf{n}$-hexane extract Muelleria lecanora.

\begin{tabular}{|c|c|c|c|c|c|}
\hline $\begin{array}{l}\text { Antibacterial } \\
\text { Compound }\end{array}$ & $\begin{array}{l}\text { Molecular } \\
\text { formula }\end{array}$ & $\begin{array}{l}\text { Methanol } \\
\text { extract } \\
\text { (\% of Area) }\end{array}$ & $\begin{array}{l}\text { Acetone } \\
\text { extract } \\
(\% \text { of Area) }\end{array}$ & $\begin{array}{l}\text { n-hexane } \\
\text { extract } \\
\text { (\% of Area) }\end{array}$ & Reported bioactivity \\
\hline $\begin{array}{l}\text { 9-Hexadecenoic acid, methyl } \\
\text { ester, (Z)(21) }\end{array}$ & $\mathrm{C}_{17} \mathrm{H}_{32} \mathrm{O}_{2}$ & 1.54 & 1.16 & - & $\begin{array}{l}\text { Antioxidant, Anti-inflammatory, antimicrobial } \\
\text { activity, and antiandrogenic flavor }{ }^{22}\end{array}$ \\
\hline Hexadecanoic Acid, Methyl Ester & $\mathrm{C}_{17} \mathrm{H}_{34} \mathrm{O}_{2}$ & 17.36 & 11.42 & - & Antimicrobial activity ${ }^{22}$ \\
\hline Tetradecanoic Acid, Methyl Ester & $\mathrm{C}_{15} \mathrm{H}_{30} \mathrm{O}_{2}$ & 0.44 & 5.49 & - & Larvicidal and repellent activity²3 \\
\hline Palmitic Acid & $\mathrm{C}_{16} \mathrm{H}_{32} \mathrm{O}_{2}$ & 0.87 & - & - & $\begin{array}{l}\text { Anti-inflammatory, lubricant, antiandrogenic, } \\
\text { nematicide, pesticide, flavor, hemolytic 5-alpha } \\
\text { reductase inhibitor, antioxidant, and } \\
\text { hypocholesterolemic }^{24}\end{array}$ \\
\hline $\begin{array}{l}\text { 9-Octadecenoic acid (Z) -, methyl } \\
\text { ester (Stearic acid methyl ester) }\end{array}$ & $\mathrm{C}_{19} \mathrm{H}_{36} \mathrm{O}_{2}$ & 14.42 & 7.36 & 10.44 & $\begin{array}{l}\text { Antileukotriene, anti-inflammatory, cancer } \\
\text { preventive, 5-alpha reductase inhibitor, } \\
\text { hypocholesterolemic, insectifuge, anemiagenic, } \\
\text { dermatitigenic, irritant, and antiandrogenic }{ }^{23}\end{array}$ \\
\hline Tetratriacontane & $\mathrm{C}_{44} \mathrm{H}_{90}$ & 4.15 & 1.39 & 14.96 & Antibacterial and antifunga $\mathrm{l}^{22}$ \\
\hline Pentacosane & $\mathrm{C}_{25} \mathrm{H}_{52}$ & 0.32 & 2.04 & 14.39 & Antitumor, antimicrobial activity, antivirus ${ }^{23}$ \\
\hline $\begin{array}{l}\text { 35,8,11,14-Eicosatetraenoic Acid, } \\
\text { Methyl Ester, (ALL-Z) or } \\
\text { EPA/Omega }\end{array}$ & $\mathrm{C}_{21} \mathrm{H}_{34} \mathrm{O}_{2}$ & 2.59 & 0.5 & - & $\begin{array}{l}\text { Preventing and managing heart disease, reduce } \\
\text { triglycerides accumulation and blood pressure, } \\
\text { anti-inflammatory complications after surgery, } \\
\text { reduce the chance of abnormal heart rhythm, } \\
\text { reduce of heart attack and stroke, slow the } \\
\text { development of plaque in the arteries }{ }^{25}\end{array}$ \\
\hline 214-Beta.-H-Pregna7890- & $\mathrm{C}_{21} \mathrm{H}_{36}$ & 1.04 & - & - & Antibacterial and antifungal effects ${ }^{26}$ \\
\hline 2-[(Hexadecyloxy)Methyl]Oxirane & $\mathrm{C}_{19} \mathrm{H}_{38} \mathrm{O}_{2}$ & 9.33 & 2.15 & - & Antibacterial activity ${ }^{27}$ \\
\hline $\begin{array}{l}\text { Stigmasta-5,22-dien-3-ol, acetate, } \\
\text { (3.beta.) }\end{array}$ & $\mathrm{C}_{31} \mathrm{H}_{50} \mathrm{O}$ & 5.79 & 8.86 & - & $\begin{array}{l}\text { Free radical Scavenging, Anti-diabetic, } \\
\text { Anticancer }{ }^{23}\end{array}$ \\
\hline Cholest-5-EN-3-YL Acetate & $\mathrm{C}_{29} \mathrm{H}_{48} \mathrm{O}_{2}$ & 7.64 & 13.61 & - & Antioxidant activity and antimicrobial activity ${ }^{28}$ \\
\hline $\begin{array}{l}\text { Ergosta-14,22-Dien-3-OL, Acetate, } \\
\text { (3.Beta.,5.Alpha.,22E)- }\end{array}$ & $\mathrm{C}_{30} \mathrm{H}_{50} \mathrm{O}_{2}$ & 4.7 & 5.89 & - & Antibacterial activity ${ }^{29}$ \\
\hline $\begin{array}{l}\text { Stigmast-5-EN-3-OL, } \\
\text { (3.Beta.,24S)- / gamma.-Sitosterol }\end{array}$ & $\mathrm{C}_{29} \mathrm{H}_{50} \mathrm{O}$ & 2.97 & 5.79 & - & $\begin{array}{l}\text { Thyroid inhibitory, antiperoxidative, and } \\
\text { hypoglycemic effects }^{23}\end{array}$ \\
\hline Octadecanoic acid, methyl ester & $\mathrm{C}_{19} \mathrm{H}_{38} \mathrm{O}_{2}$ & 13.34 & 4.37 & - & Antimicrobial activity ${ }^{23}$ \\
\hline Caryophyllene & $\mathrm{C}_{15} \mathrm{H}_{24}$ & - & 0.42 & - & Anti-inflammatory and Antimicrobial activity ${ }^{30}$ \\
\hline $\begin{array}{l}\text { Azulene, 1,2,3,5,6,7,8,8a-octahydro- } \\
\text { 1,4-dimethyl-7-(1-methylethenyl)-, } \\
\text { [1S-(1.alpha.,7.al) }\end{array}$ & $\mathrm{C}_{15} \mathrm{H}_{24}$ & - & 7.53 & - & $\begin{array}{l}\text { Analgesic, antiasthamatic, anti-inflammatory, and } \\
\text { antipyretic properties }{ }^{20}\end{array}$ \\
\hline Heneicosane & $\mathrm{C}_{21} \mathrm{H}_{44}$ & - & - & 32.91 & Anticancer $^{31}$ \\
\hline Docosane & $\mathrm{C}_{22} \mathrm{H}_{46}$ & - & - & 13.44 & Anti-inflammatory and anti-atherogenic ${ }^{32}$ \\
\hline
\end{tabular}


and anti-tumor activity. ${ }^{33}$ Moreover, they have impressive amounts of lectins, glycosaminoglycans, omega-6, omega-3 fatty acids (EPA and DHA), and sterols. ${ }^{34}$

GC-MS test showed forty peaks and components in the nhexane extract of sea cucumber (Figure 3). Only five were important as pharmacological material, namely Heneicosane $(32.91 \%)$, Tetratriacontane $(14,96 \%)$, Pentacosane (14.39\%), Docosane (13.44\%), and 9-Octadecenoic acid (Z) -, methyl ester (10.44\%). There are two exciting compounds to be examined and not found by the other two solvents (methanol and acetone), namely Heneicosane. This serves as an anti-cancer and Docosane antiinflammatory and anti-atherogenic. Isolation of brown algae Lobophora variegata from the Brazilian coastal produced polyunsaturated epoxy-heneicosane compounds that serve as antiproliferative, better tumor cell line inhibition compared to fibroblast. ${ }^{31}$ Furthermore, compounds found in brown algae have similarities with those in sea cucumbers Muellaria lacenora such asPolyunsaturated Fatty Acids (PUFAs), 5,8,11,14Eicosatetraenoic Acid, Methyl Ester, (ALL-Z) EPA/Omega 3 (DHA), and Eicosapentaenoic Acid (EPA). ${ }^{31,35}$ Compounds n-3 PUFAs may increase the sensitivity of tumor cells to conventional therapies. These molecules exhibit anti-tumor activity by inducing apoptosis in human cancer cells alone or combined with conventional chemotherapy agents. ${ }^{36-38}$ Microdilution method of Heneicosane compounds as antibacterial activity against two gram-positive bacterial types Salmonella (ATCC 29890) and Staphylococcus aureus (ATCC 6538P) was also conducted. Bacteria gram-negative strains Escherichia coli (ATCC 10536) did not give good results. ${ }^{31}$

\section{Antibacterial activity}

Table 2 showed that antibacterial activity in sea cucumber extracts was measured against three bacterial strains (two grampositive and one gram-negative).

Screening for sensitivity against the three solvents extracts methanol, acetone, and n-hexane extract of sea cucumber leaves was calculated as $20 \mu \mathrm{L}$. Furthermore, Muelleria lecanora was screened for antimicrobial activity through the Kirby-Bauer disc diffusion assay on bacterial strains Escherichia coli (gram-negative), Salmonella (gram-positive), and Staphylococcus aureus (gram-positive). ${ }^{39}$ Antibacterial activity less than $6 \mathrm{~mm}$ was classified as inactive, mildly active $(6-7 \mathrm{~mm})$, medium active $(7-10 \mathrm{~mm})$, and highly active $(>10 \mathrm{~mm}) .{ }^{18}$ In addition, the inhibitory zone $\geq 6$ $\mathrm{mm}$ and maximum zone for Staphylococcus aureus $(10,94 \mathrm{~mm})$ were immune to all strains. Broad-spectrum showed a minimum zone of $6.09 \mathrm{~mm}$ for methanol extract at $60 \mathrm{~min}$ extraction against bacteria Escherichia coli and acetone extract at 30 min extraction against Staphylococcus aureus at a maximum zone of $10.94 \mathrm{~mm}$.

\section{Antibacterial activity against Escherichia coli}

The antibacterial activity in n-hexane solvents with extraction times of 30, 60, 90, and 120 min was not recommended for biological activities, since the resulting diameter spectrum $<7.44 \mathrm{~mm}$. All three solvents belonged to the slightly active category with an average inhibitory zone of 6-7 $\mathrm{mm}$ (Table 2 and Figure 4).

\section{Antibacterial activity against Salmonella}

Disc diffusion assay method was used to determine antimicro-
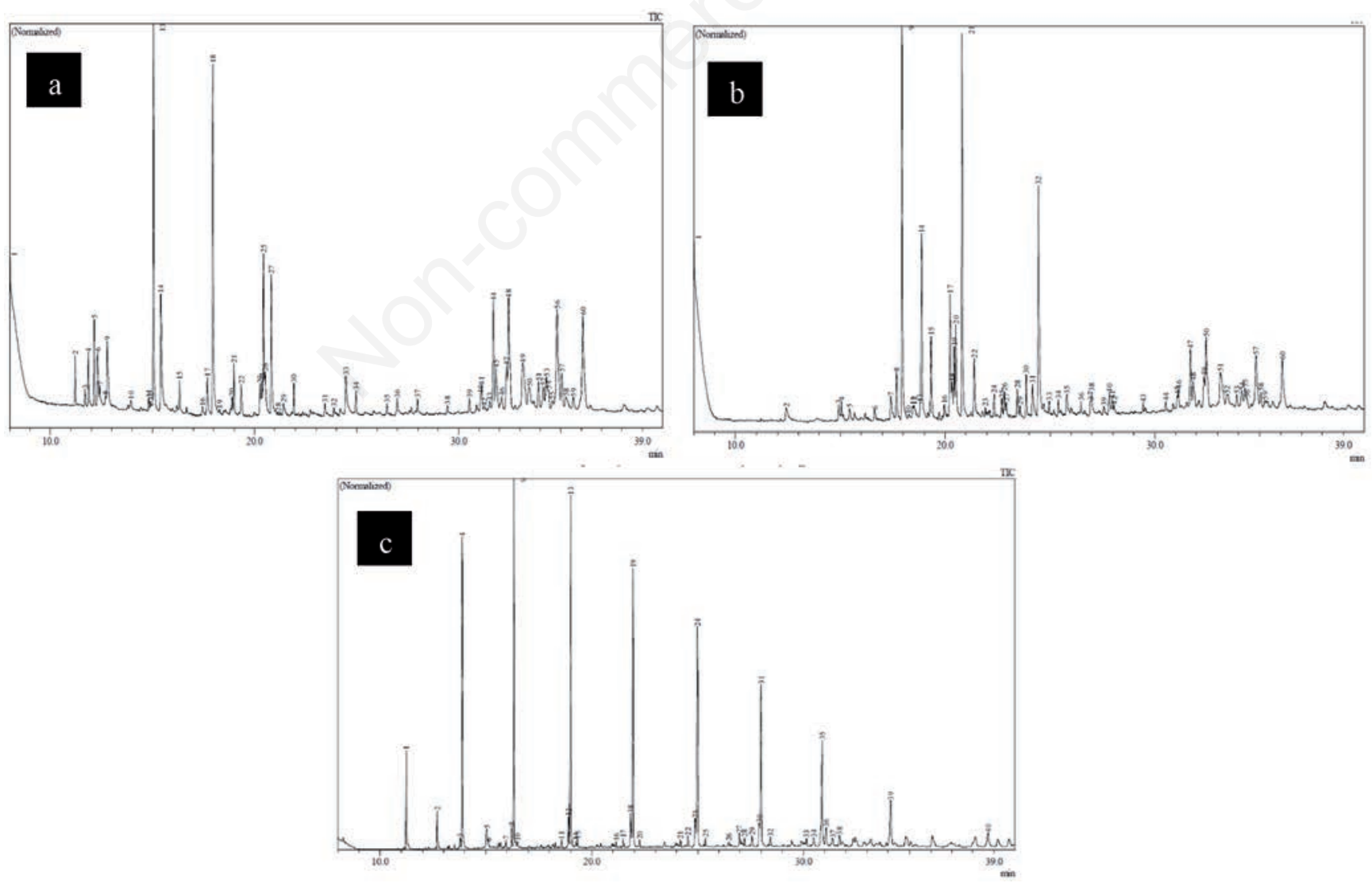

Figure 3. Chromatogram of sea cucumbers Muelleria lecanora extract: a. methanol solvent; $b$. acetone solvent; c. $n$-hexane solvent. 
bial agent activity, through a disc. The antibacterial agent was put on the media to plant microorganisms that will diffuse. ${ }^{16}$ Clear areas indicate a growth barrier of microorganisms on the media surface. The advantages of this method are the number of substances used can be arranged. Furthermore, acetone extract with 90 min extraction has a minimum zone diameter of $6.52 \mathrm{~mm}$, and n-hexane with 60 min extraction has a maximum zone diameter of $8.82 \mathrm{~mm}$ against Salmonella. These results also showed that acetone, methanol, and n-hexane extracts have mild active activity against Salmonella with a diameter of inhibitory zone $7-10 \mathrm{~mm}$ (Table 2 and Figure 5).

\section{Antibacterial activity against Staphylococcusaureus}

Methanol extract with 120 min extraction has a minimum zone diameter of $6.37 \mathrm{~mm}$. Meanwhile, acetone extract with 30 min extraction has a maximum zone diameter of $10.94 \mathrm{~mm}$ against Staphylococcus aureus. These results also showed acetone, methanol, and n-hexane extracts have highly active activity against Salmonella with a diameter of inhibitory zone $>10 \mathrm{~mm}$ (Table 2 and Figure 6). Their preliminary antibacterial assay of sea cucumber Muellaria lecanora showed different responses to the test strains against bacteria gram-positive (Salmonella and Staphylococcus aureus). However, they are not recommended for gram-negative bacteria such as Escherichia coli.

\section{Conclusions}

Ultrasonic-assisted extraction was a practical and valuable method for extracting potential antioxidants from sea cucumber. In summary, acetone, methanol, and n-hexane were excellent solvents for the extraction of bioactive compounds from Sea cucumbersMuelleria lecanora. Bioactive compounds extracted using n-hexane solvent served as a new antiproliferative polyun- saturated epoxy-heneicosane with better inhibition of the tumor cell and anti-cancer. Furthermore, the GC-MS study indicated the existence of a good number of bioactive metabolites, such as flavonoids and steroids. Therefore,sea cucumbers Muelleria lecanora showed higher free radical scavenging and may be used in therapeutic applications and food products (functional foods). In addition, it has an effective antibacterial activity on Salmonella and Staphylococcus aureus, and evaluation showed that the entire extract had antibacterial potential.

\section{References}

1. Zhong Y, Khan MA, Shahidi F. Compositional characteristics and antioxidant properties of fresh and processed sea cucumber (Cucumaria frondosa). J Agric Food Chem 2007;55:1188-92.

2. Wang T, Sun Y, Jin L, et al. Aj-rel and Aj-p105, two evolutionary conserved NF- $\kappa \mathrm{B}$ homologues in sea cucumber (Apostichopus japonicus) and their involvement in LPS induced immunity. Fish Shellfish Immunol 2013;34:17-22.

3. Lee HW, Lim NL, Cho K, et al. Characterisation of inorganic elements and volatile organic compounds in the dried sea cucumber Stichopus japonicus. Food Chem 2014;147:34-41.

4. Chen J. Present status and prospects of sea cucumber industry in China. Food and Agriculture Organization of the United Nations. 2004.

5. Mills D, Duy NDQ, Juinio-Menez M a, et al. Overview of sea cucumber aquaculture and sea-ranching research in the SouthEast Asian region. Proceedings of an international symposium held in Noumea, New Caledonia, 15-17 February 2011. ACIAR Proceedings No. 136. Australian Centre for International Agricultural Research, Canberra.

6. Wen J, Hu C, Fan S. Chemical composition and nutritional quality of sea cucumbers. J Sci Food Agric 2010;90:2469-74.

Table 2. Zone of inhibition test extract of sea cucumber Muellaria lecanoraagainst different pathogens.

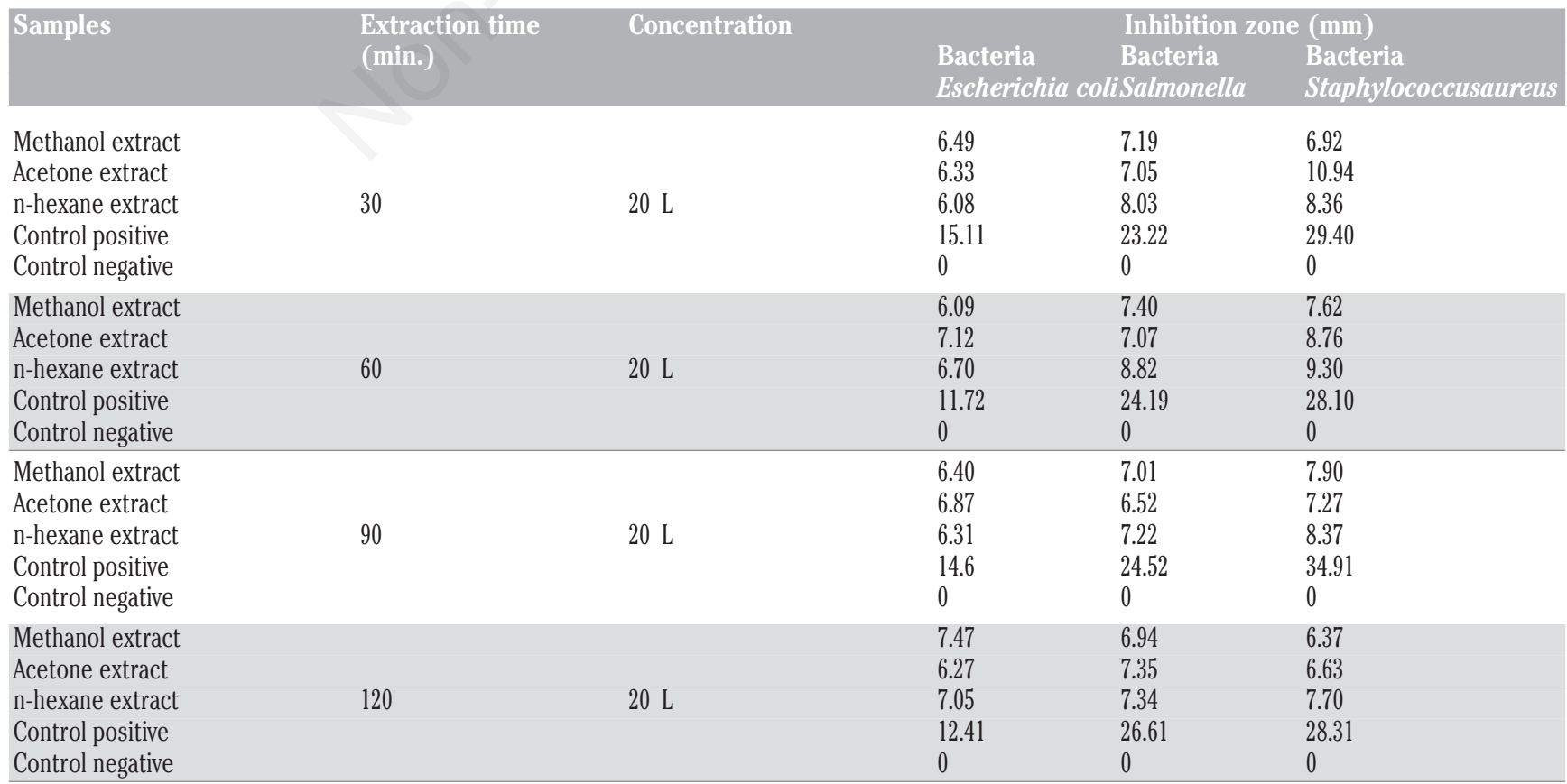



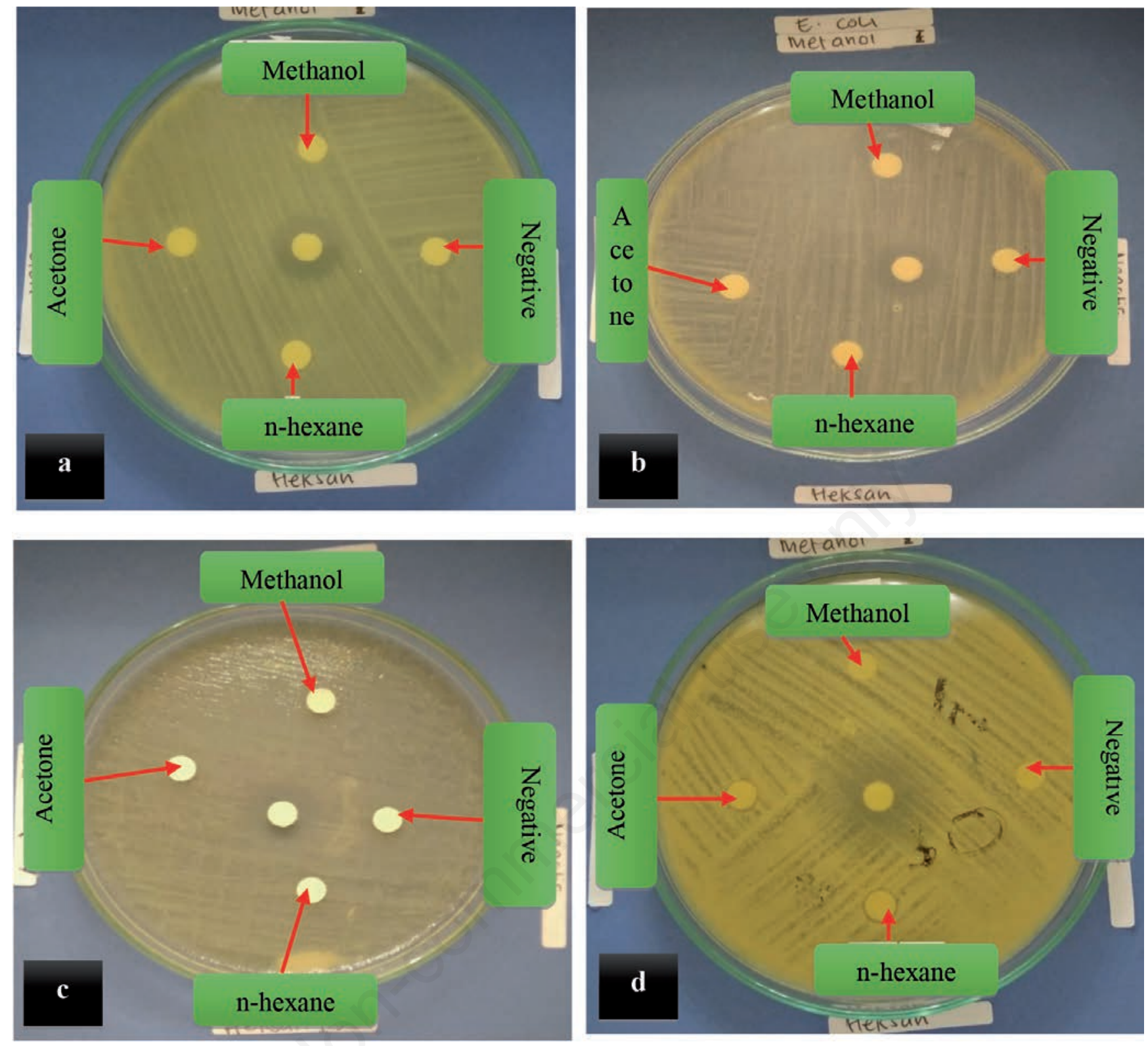

Figure 4. Antibacterial activity of acetone, methanol, and n-hexane extract sea cucumber against Escherichia coli: a) 30 min extraction; b) $60 \mathrm{~min}$ extraction; c) $90 \mathrm{~min}$ extraction, and d) $120 \mathrm{~min}$ extraction.

7. Li C, Haug T, Styrvold OB, et al. Strongylocins, novel antimicrobial peptides from the green sea urchin, Strongylocentrotus droebachiensis. Dev Comp Immunol 2008;32:1430-40.

8. Mohammadizadeh F, Ehsanpor M, Afkhami M, et al. Antibacterial, antifungal and cytotoxic effects of a sea cucumber Holothuria leucospilota, from the north coast of the Persian Gulf. J Mar Biol Assoc United Kingdom 2013;93: 1401-5.

9. Mohammadizadeh F, Ehsanpor M, Afkhami M, et al. Evaluation of antibacterial, antifungal and cytotoxic effects of Holothuria scabra from the North Coast of the Persian Gulf. J Mycol Med 2013;23:225-9.

10. Jiang J, Zhou Z, Dong Y, et al. Invitro antibacterial analysis of phenoloxidase reaction products from the sea cucumber
Apostichopus japonicus. Fish Shellfish Immunol 2014;39: 458-63.

11. Darya M, Sajjadi MM, Yousefzadi M, et al. Antifouling and antibacterial activities of bioactive extracts from different organs of the sea cucumber Holothuria leucospilota. Helgol Mar Res 2020;74:4.

12. Pangestuti R, Arifin Z. Medicinal and health benefit effects of functional sea cucumbers. J Tradit Complement Med 2018;8: 341-51.

13. Liao N, Zhong J, Ye X, et al. Ultrasonic-assisted enzymatic extraction of polysaccharide from Corbicula fluminea: Characterization and antioxidant activity. Food Sci Technol Campinas 2020;40:36-45.

14. Muhammad DRA, Praseptiangga D, Van de Walle D, 

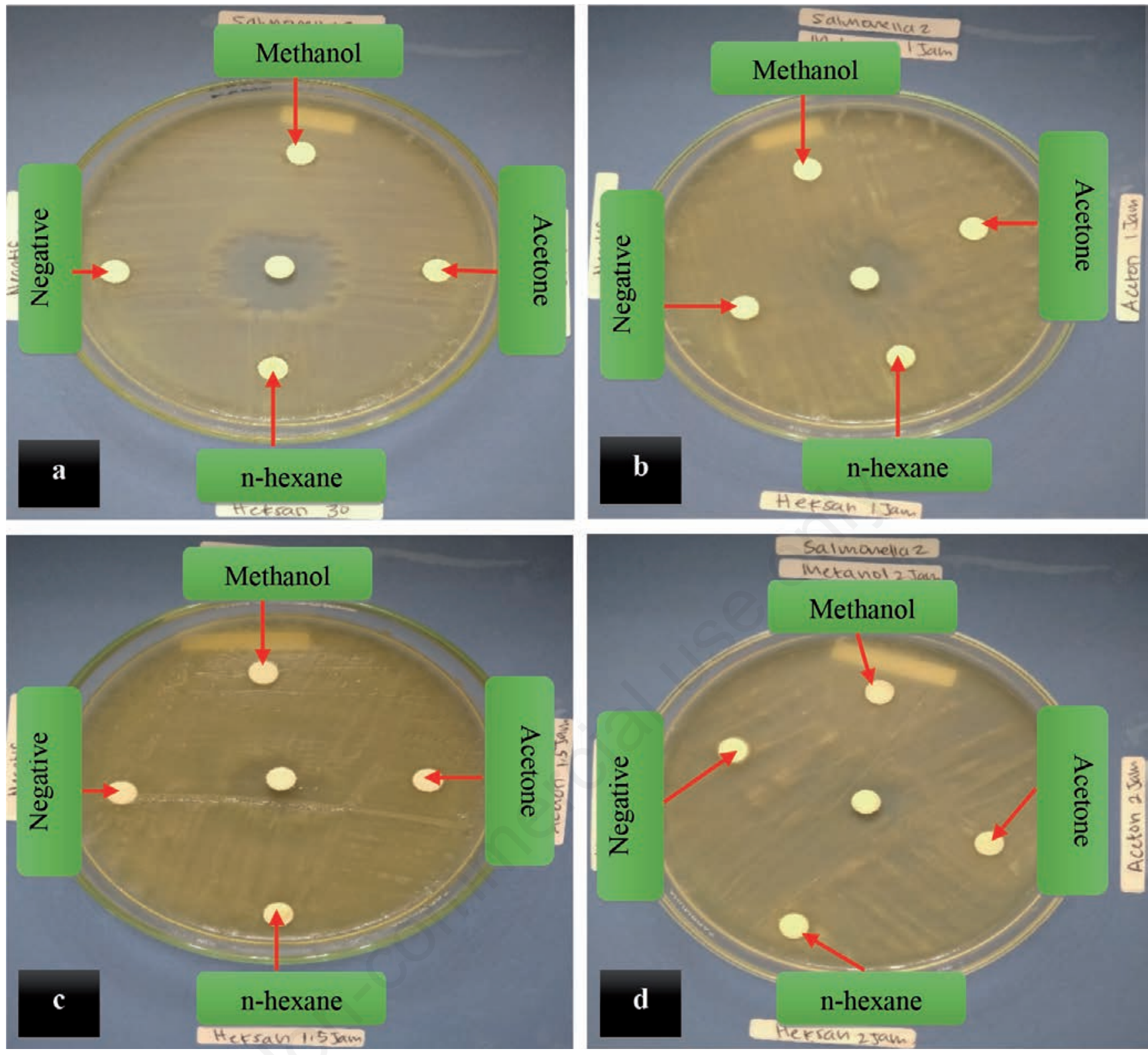

Figure 5. Antibacterial activity of acetone, methanol, and $\mathbf{n}$-hexane extract sea cucumber against Salmonella: a) 30 min extraction; b) $60 \mathrm{~min}$ extraction; c) $90 \mathrm{~min}$ extraction, and d) $120 \mathrm{~min}$ extraction.

Dewettinck K. Interaction between natural antioxidants derived from cinnamon and cocoa in binary and complex mixtures. Food Chem 2017;231:356-64.

15. Misra NN, Martynenko A, Chemat F, et al. Thermodynamics, transport phenomena, and electrochemistry of external fieldassisted nonthermal food technologies. Crit Rev Food Sci Nutr 2018;58:1832-63.

16. Yusuf M, Fitriani Nur UA, Rifai A. In vitro antibacterial activity and potential applications in food of sea urchin (Diadema setosum) from Cape of Palette, South Sulawesi. Food Res 2020;4:2139-46.

17. Afifi R, Abdel-Nabi IM, El-Shaikh K. Antibacterial activity from soft corals of the Red Sea, Saudi Arabia. J Taibah Univ Sci 2016;10:887-95.
18. Chandra R, Dwivedi V, Shivam K, Jha AK. Detection of antimicrobial activity of Oscimum sanctum (Tulsi) \& trigonella foenum graecum (Methi) against some selected bacterial \& fungal strains. Res J Pharm Biol Chem Sci 2011;2:809-13.

19. Yusuf M, Atthamid NFU, Indriati S, Saleh R, Latief M, Rifai A. Optimization ultrasonic assisted extraction (UAE) of bioactive compound and antibacterial potential from sea urchin (diadema setosum). Curr Res Nutr Food Sci 2020;8:556-69.

20. Hameed IH, Hussein HJ, Kareem MA, Hamad NS. Identification of five newly described bioactive chemical compounds in Methanolic extract of Mentha viridis by using gas chromatography - mass spectrometry (GC-MS). J Pharmacogn Phyther 2015;7:107-25.

21. Suluvoy JK, Berlin Grace VM. Phytochemical profile and free 

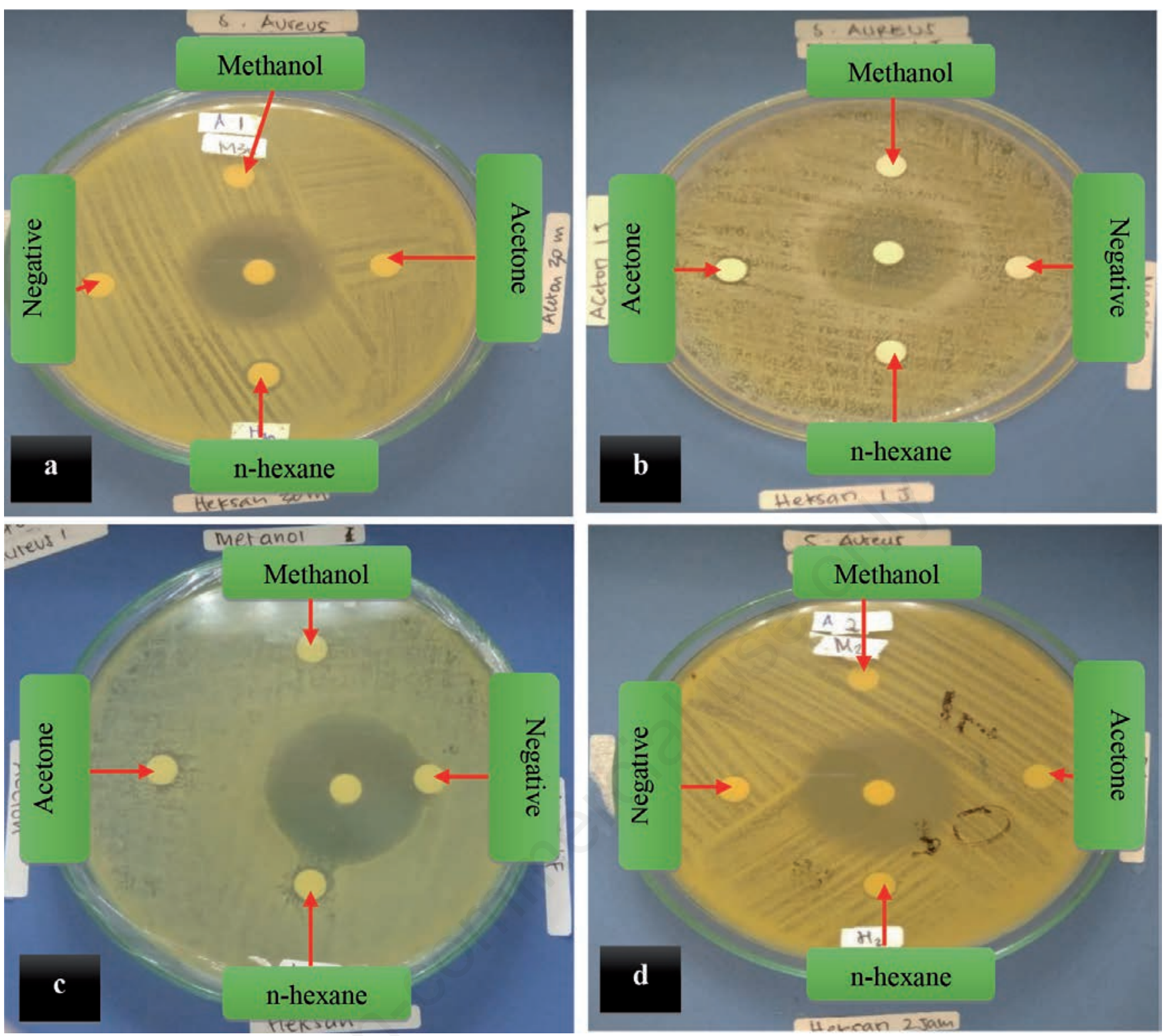

Figure 6. Antibacterial activity of acetone, methanol, and $\mathbf{n}$-hexane extract sea cucumber against Staphylococcus aureus: a) 30 min extraction; b) $60 \mathrm{~min}$ extraction; c) 90 min extraction, and d) $120 \mathrm{~min}$ extraction.

radical nitric oxide (NO) scavenging activity of Averrhoa bilimbi L. fruit extract. 3 Biotech 2017;6:1-11.

22. Yusuf M, Fitriani Nur UA, Mahyati L, Imran M. Phytochemical and antibacterial properties of sea cucumber (Muelleria lecanora) from Barrang Lompo Islands, Makassar South Sulawesi. Food Res 2020;4:1885-95.

23. Abubakar M, Majinda R. GC-MS Analysis and preliminary antimicrobial activity of Albizia adianthifolia (Schumach) and Pterocarpus angolensis (DC). Medicines 2016;3:1-9.

24. Anwar F, Latif S, Ashraf M, Gilani AH. Moringa oleifera: A food plant with multiple medicinal uses. Phyther Res 2007;21:17-25.

25. Yi T, Li SM, Fan JY, et al. Comparative analysis of EPA and DHA in fish oil nutritional capsules by GC-MS. Lipids Health Dis 2014;13:190.
26. Dehpour AA, Yousefian M, Jafary Kelarijani SA, et al. Antibacterial activity and composition of essential oils of flower allium rotundum. Adv Environ Biol 2012;6:1020-5.

27. Henry Wright M, Jean Arnold MS, Aldosary H, et al. Bioactive constituents of Terminalia ferdinandiana Exell: A pharmacognistic approach towards the prevention and treatment of yersiniosis. Pharmacogn Commun 2016;6:152-63.

28. Singh A, Palariya D, Dhami A, et al. Biological activities and Phytochemical analysis of Zanthoxylum armatum DC. leaves and bark extracts collected from Kumaun region, Uttarakhand, India. J Med Herbs Ethnomedicine 2020;6:1-10.

29. Putra MY, Hadi TA. Chemical composition, antimicrobial, cytotoxic and antiplasmodial activities of three sponges from Buton Islands, Indonesia. Indones J Mar Sci 2017;22:147-54. 30. Manjamalai A, Alexander T, Berlin Grace VM. Bioactive eval- 
uation of the essential oil of plectranthus amboinicus by GCMS analysis and its role as a drug for microbial infections and inflammation. Int J Pharm Pharm Sci 2012;4:205-11.

31. Ávila FN, Pinto FCL, Carneiro PBM, et al. New antiproliferative polyunsaturated epoxy-heneicosane derivatives isolated from the brown alga lobophora variegata. J Braz Chem Soc 2019;3:406-12.

32. Uraku AJ. GC/MS determination of bioactive constituents of methanol fraction of Spilanthes uliginosa (SW) leaves. Res J Med Plant 2016;10:42-54.

33. Han H, Yi YH, Li L, et al. Triterpene glycosides from sea cucumber Holothuria leucospilota. Chin J Nat Med 2009;7:346-50.

34. Silchenko AS, Avilov SA, Kalinin VI, et al. Constituents of the sea cucumber Cucumaria okhotensis. Structures of okhotosides B1-B3 and cytotoxic activities of some glycosides from this species. J Nat Prod 2008;71:351-6.
35. Abedi E, Sahari MA. Long-chain polyunsaturated fatty acid sources and evaluation of their nutritional and functional properties. Food Sci Nutr 2014;2:443-46.

36. Zhou JK, Zheng YZ, Liu XS, et al. ROR1 expression as a biomarker for predicting prognosis in patients with colorectal cancer. Oncotarget 2017;8:32864-72.

37. Murray M, Hraiki A, Bebawy M, et al. Anti-tumor activities of lipids and lipid analogues and their development as potential anticancer drugs. Pharmacol Ther 2015;150:109-28.

38. Lee ES, Son DS, Kim SH, et al. Prediction of recurrence-free survival in postoperative non-small cell lung cancer patients by using an integrated model of clinical information and gene expression. Clin Cancer Res 2008;14:7397-404.

39. Sharma A, Gupta S, Sarethy IP, et al. Green tea extract: Possible mechanism and antibacterial activity on skin pathogens. Food Chem 2012;135:672-5. 